\section{Mulched Maple and Oak Leaves Associated with a Reduction in Common Dandelion Populations in Established Kentucky Bluegrass}

\author{
Alexander R. Kowalewski1 ${ }^{1,6}$, Douglas D. Buhler ${ }^{2}$, N. Suzanne Lang ${ }^{3}$, \\ Muraleedharan G. Nair ${ }^{4}$, and John N. Rogers, III',5
}

AdDitional InDEx wORDs. turf, mowing, Acer, Taraxacum officinale, organic weed control, ecology

Summary. Previous research has shown that maple (Acer spp.) leaf litter resulted in fewer common dandelions (Taraxacum officinale) when mulched into established turfgrass. However, the leaves used in that research may have contained herbicide residues and were separated by genus, not species. Our research compared the effects of pesticide-free mulched maple and oak (Quercus spp.) leaves on dandelion populations in an established kentucky bluegrass (Poa pratensis) stand maintained as a residential lawn on sandy loam soil. The objectives of this study were to quantify the effectiveness of maple or oak leaf mulches as an organic common dandelion control method and to identify which maple species and rates (particle size and rate per unit area) provided the most effective control. The experimental design was a randomized complete block with treatments arranged as a $5 \times 2 \times 2+1$ factorial, with tree leaf species, leaf particle size, leaf application rate, and control as main factors. Leaf species were red maple (Acer rubrum), silver maple (A. saccharinum), sugar maple (A. saccharum), high sugar content sugar maple, and red oak (Quercus rubva). Particle sizes were coarse $\left(0.4-1.0 \mathrm{inch}^{2}\right)$ and fine $\left(\leq 0.2 \mathrm{inch}^{2}\right)$, and application rates were low $\left(0.5 \mathrm{~kg} \cdot \mathrm{m}^{-2}\right)$ and high $\left(1.5 \mathrm{~kg} \cdot \mathrm{m}^{-2}\right)$. Mulch applications were made in Fall 2003 and 2004 and data were collected beginning in Spring 2004 on kentucky bluegrass spring green-up, and common dandelion plant counts. The high application rate, regardless of tree genus or species, resulted in the highest green-up ratings. Common dandelion plant counts after one (2003) and two (2003 and 2004) mulch applications at the high rate showed that up to $80 \%$ and $53 \%$ reduction was achieved, respectively. Results indicate that mulching leaves regardless of genus (oak or maple) or maple species into established turfgrass as a leaf litter disposal method will increase spring green-up and contribute to a reduction in common dandelion population.

$\mathrm{R}$ esearch in the field of turfgrass management has been exploring the use of organically derived nonchemical weed control methods in response to the criticism that synthetic herbicides are

This paper is a portion of a thesis submitted by Alexander R. Kowalewski in fulfillment of Master's of Science degree requirements.

${ }^{1}$ Department of Crop and Soil Sciences, Al62 Plant and Soil Science Building, Michigan State University, East Lansing, MI 48823

${ }^{2}$ Department of Agriculture and Natural Resources, 109 Agriculture Hall, Michigan State University, East Lansing, MI 48823

${ }^{3}$ Department of Horticulture, A322 Plant and Soil Science Building, Michigan State University, East Lansing, MI 48823

${ }^{4}$ Department of Horticulture, 173 Food Safety and Toxicology Building, Michigan State University, East Lansing, MI 48823

${ }^{5}$ Department of Crop and Soil Science, Al60 Plant and Soil Science Building, Michigan State University, East Lansing, MI 48823

${ }^{6}$ Corresponding author. E-mail: kowalew8@msu.edu. potentially harmful to the environment (Bingaman and Christians 1995; Starrett et al., 2000). One of the potential organic alternatives, corn (Zea mays) gluten meal, inhibits the formation and growth of roots of several monocotyledon and dicotyledonous weed species, particularly crabgrass (Digitaria spp.) (Bingaman and Christians, 1995). Soybean meal, another agricultural plant byproduct, provided up to $55 \%$ reduction in common dandelion populations in turf (Tompkins et al., 2004).

Research at Michigan State University (MSU) exploring tree leaf mulching as a leaf litter disposal method determined that maple and oak leaf litter could be mulched into established turfgrass with no apparent deleterious effects (i.e., decreased turfgrass color or quality) (Nikolai et al., 1998). Unrelated to the objectives of that initial research, turfgrass plots that were treated with maple leaf mulch had fewer common dandelions than the oak leaf-treated or control plots. These findings suggested that mulched maple leaves may provide selective common dandelion control in established turfgrass. However, the leaves used in that research were collected from the MSU campus, which uses an integrated pest management (IPM) turfgrass management program that includes the applications of broadleaf herbicides. Therefore, the observed results could have been confounded by potential herbicide residues on the collected leaves because residual analysis of these leaves was not conducted. The leaves in this research were also collected indiscriminately and separated by genus, making it impossible to determine if a particular maple or oak species was capable of providing better control than others.

These findings triggered our subsequent study designed to compare the effects of mulched leaves, collected from a variety of herbicidefree maple and oak species, on established turfgrass as an organic broadleaf weed control method. The specific objectives of this research were to first quantify the effectiveness of four maple and one oak species leaf mulch as an organic broadleaf weed control method in an established kentucky bluegrass turfgrass stand

\begin{tabular}{llll}
\hline $\begin{array}{l}\text { Units } \\
\begin{array}{l}\text { To convert U.S. to SI, } \\
\text { multiply by }\end{array}\end{array}$ & U.S. unit & SI unit & $\begin{array}{l}\text { To convert SI to U.S., } \\
\text { multiply by }\end{array}$ \\
\hline 0.0929 & $\mathrm{ft}^{2}$ & $\mathrm{~m}^{2}$ & 10.7639 \\
2.54 & inch(es) & $\mathrm{cm}$ & 0.3937 \\
6.4516 & inch & $\mathrm{cm}^{2}$ & 0.1550 \\
0.4536 & $\mathrm{lb}$ & $\mathrm{kg}$ & 2.2046 \\
48.8243 & $\mathrm{~b} / 1000 \mathrm{ft}^{2}$ & $\mathrm{~kg} \cdot \mathrm{ha}^{-1}$ & 0.0205 \\
4.8824 & $\mathrm{lb} / \mathrm{ft}^{2}$ & $\mathrm{~kg} \cdot \mathrm{m}^{-2}$ & 0.2048 \\
305.1517 & $\mathrm{oz} / \mathrm{ft}^{2}$ & $\mathrm{~g} \cdot \mathrm{m}^{-2}$ & 0.0033 \\
1.1692 & $\mathrm{pt} / \mathrm{acre}$ & $\mathrm{L} \cdot \mathrm{ha}^{-1}$ & 0.8553 \\
$\left({ }^{\circ} \mathrm{F}-32\right) \div 1.8$ & ${ }^{\circ} \mathrm{F}$ & ${ }^{\circ} \mathrm{C}$ & $\left(1.8 \times{ }^{\circ} \mathrm{C}\right)+32$
\end{tabular}


under Michigan environmental conditions. The second objective of this work was to identify specific maple species that provide effective broadleaf weed control. The final two objectives of this research were to determine the optimum leaf litter particle size and rate per unit area for the most effective broadleaf weed control. The original hypothesis of this work was that a specific maple species ground to a fine particle size and applied at the high application rate would provide the most effective common dandelion control. Our work presents the opportunity to identify a new method of organic broadleaf weed (specifically common dandelion) control.

\section{Materials and methods}

Field experimentation was initiated Aug. 2003 at the Hancock Turfgrass Research Center (HTRC; East Lansing, MI). The total experimental area was $2448 \mathrm{ft}^{2}$, divided into three blocks, each with a total of 24 treatments $\left(30.0 \mathrm{ft}^{2}\right)$. Factors included tree leaf species, leaf particle size, leaf application rate, and a control, which did not receive any mulch. Leaf species were red maple, silver maple, sugar maple, high sugar content (HSC) sugar maple, and red oak. Particle sizes were fine $\left(\leq 0.2\right.$ inch $\left.^{2}\right)$ and coarse (0.4-1.0 inch $\left.^{2}\right)$, and application rates were low $\left(0.5 \mathrm{~kg} \cdot \mathrm{m}^{-2}\right)$ and high $\left(1.5 \mathrm{~kg} \cdot \mathrm{m}^{-2}\right)$. A control, which did not receive any mulch, was also included. Research was conducted on 'Fylking' kentucky bluegrass established in 1992 on an Aubbeenaubbee sandy loam soil (fine-loamy, mixed, active, mesic Aeric Epiaqualfs) (National Resources Conservation Services, 2005). Before the initiation of this research, the experimental area was maintained at a 4.0 -inch mowing height, received $\approx 3.0 \mathrm{lb} / 1000 \mathrm{ft}^{2}$ nitrogen annually (products and rates varied slightly from year to year), and an annual application of a selective broadleaf herbicide (time of year, product, and application rate varied from year to year). A three-way herbicide, 2,4-D + methylchlorophenoxypropionic acid (MCPP) + dicamba (Trimec $^{\circledR}$ Classic Broadleaf Herbicide; PBI/Gordon, KS City, MO.), was applied at a rate of $1.3 \mathrm{pt} /$ acre a.i. to the experimental sites on 19 Aug. 2003 to eliminate existing broadleaf weeds.
Site PREPARATION. Three days after the herbicide application, the turfgrass coverage was reduced by scalping (mowing removal of an excessive quantity of green leaves, resulting in brown turfgrass) to 1.0 inch and verticutting (using vertically rotating blades that cut into the turf to reduce thatch and expose bare soil) to insure dandelion seed germination in 2003 (Letchamo and Gosselin, 1996). Debris produced during scalping and verticutting were removed to increase common dandelion seed to soil contact when the seeds were later sown. Standard fertilizer, herbicide applications, and irrigation practices were also eliminated at this time to further decrease turfgrass health and vigor, allowing weeds like common dandelion to thrive. Soil samples of the top 4.0 inches were collected to determine the existing soil $\mathrm{pH}$ and nutrient levels of the experimental area $(\mathrm{pH}$ $7.4,30.0$ ppm phosphorus, and 182.0 ppm potassium; MSU University Soil and Plant Nutrient Laboratory, East Lansing). Common dandelion seeds from a 2001 seed lot (V \& J Seed, Woodstock, IL) were applied on 11 Sept. 2003, the same day they were received from the seed company, using a drop spreader. Common dandelion seeds were applied at a rate of $\approx 2600$ seeds $/ \mathrm{m}^{2}$. Stevens (1957) determined that a single dandelion can produce 1200 seeds, which would suggest that the seed rate described above was equivalent to $\approx 2$ seed producing dandelions/ $\mathrm{m}^{2}$. The Michigan Department of Agricultural Control Laboratory (East Lansing) determined germination rates of $9.3 \%$ using a $2 \mathrm{l}$-d germination test with a daily cycle of $16 \mathrm{~h}$ at $20{ }^{\circ} \mathrm{C}$ and $8 \mathrm{~h}$ at $30{ }^{\circ} \mathrm{C}$, which conformed to the Association of Official Seed Analysts rules for testing common dandelion (Association of Official Seed Analysts, 2002).

Tree leaf collection, PREPARATION, AND APPLICATION. Deciduous tree leaves were collected at the W.K. Kellogg Forest (Augusta, MI). Collection traps were installed on 25 Sept. 2003 in monoculture, pesticide-free plantations of each of the tree species used in our study. HSC sugar maple seedlings had been transplanted from the Akens Sugar Maple Laboratory (Burlington, VT), where they were selected for high sap sugar content using a refractometer, to the W.K. Kellogg Forest in 1977. In each plantation, leaf litter traps of various sizes totaling $1180.0 \mathrm{ft}^{2}$ were installed on the forest floor to prevent the leaves from making direct contact with the underlying soil. Cloth germination blankets were used to make the litter traps, which were pinned to the base of the trees and folded along the edges to create 4.0 -inch walls to prevent the wind from blowing the leaves away. From 17 to 20 Oct. 2003, at the peak of leaf fall, 100 $\mathrm{lb}$ of leaves of each species were collected from the leaf litter traps. A lawn blower/vacuum (Poulan $\mathrm{PRO}^{\circledR}$ \#BMV-200 Gas Blower/Vac; Electrolux Home Products, Nashville, AR) was used to collect the leaves, which were then placed in plastic trash bags.

After the leaves were transported to HTRC on 21 Oct. 2003, random samples from each bag were weighed, dried for $48 \mathrm{~h}$ in a $140^{\circ} \mathrm{C}$ oven, and weighed again so the leaves could be applied at identical rates regardless of the moisture content. After determining the moisture content of the leaves, half the contents of each bag $(50 \mathrm{lb})$ was ground to a fine particle size by a MacKissic $^{\circledR}$ Mighty Mac ${ }^{\mathrm{TM}}$ mulcher (West Power Products, Thorndale, PA) equipped with a 0.2 -inch ${ }^{2}$ metal screen. Leaves were ground before application with the idea that reducing particle size may accelerate the biodegradation process and release potential plant-derived weed inhibitor compounds at a faster rate (Lodhi, 1976). The remaining $50 \mathrm{lb}$ of leaves was applied at a coarse particle size, ranging from 0.4 to $1.0 \mathrm{inch}^{2}$, the result of the collection process.

First application (2003). Two weeks before initial leaf treatment applications (15 Oct. 2003) 2,4-D + MCPP + dicamba was applied again at a rate of $1.3 \mathrm{pt} /$ acre a.i. because late fall common dandelion emergence was observed. On 31 Oct. 2003, the four maple species leaf treatments were randomly applied to the experimental area, along with the oak leaves at two rates (low and high) and two particle sizes [fine $(\leq 0.2$ inch $\left.^{2}\right)$ and coarse (0.4 to 1.0 inch $\left.\left.^{2}\right)\right]$. A control treatment did not receive a leaf mulch application to compare the effects of plots treated with mulched leaves to plots without mulched leaves. The low rate, $0.5 \mathrm{~kg} \cdot \mathrm{m}^{-2}$ of dried leaves, was equivalent to $3.1 \mathrm{lb}$ 
per $30.0-\mathrm{ft}^{2}$ plot, similar to rates that naturally fell from the trees that they were collected from, and the high rate, $1.5 \mathrm{~kg} \cdot \mathrm{m}^{-2}$ of dry leaves, was equivalent to $9.2 \mathrm{lb}$ per $30.0-\mathrm{ft}^{2}$ plot. All plots were mowed with a rotary push mower set to 2.0 inches on 5 Nov. 2003 to ensure that the mulched leaves were incorporated into the turfgrass canopy.

SECOND APPLICATIONS (2004). The experimental site received a second consecutive annual application of mulched leaves in 2004. Common dandelion seeds received 20 Oct. 2004 were applied at a rate $\approx 2292$ seeds $/ \mathrm{m}^{2}$ on 28 Oct. 2004. A germination rate of $0.66 \%$ was determined by the Michigan Department of Agricultural Control Laboratory, likely because seed used in 2003 and 2004 came from the same seed lot collected in 2001. However, this reduction in germination was not anticipated and seeds were applied at a rate similar to that of 2003. Freshly fallen tree leaves were collected from 23 to 27 Oct. 2004 and were then applied at the appropriate rates, adjusted according to moisture content, and particle sizes on 11 Nov. 2004. The leaf applications were then mowed into the turfgrass canopy on 16 Nov. 2004. The experimental area was not verticut or scalped and did not receive an herbicide treatment in 2004, allowing for assessment of the postemergent effects of the leaf mulch treatments on the dandelion population that were sowed in 2003.

Site management. Primary cultural practices (mowing, fertilization, and irrigation) were adjusted throughout the year to promote weed establishment yet prevent total turfgrass loss. From 26 Apr. to 6 July 2004 and 2005 , the experimental area was managed with minimal inputs to promote dandelion growth and establishment. This included no irrigation and no fertilization, which are required for maintaining high turfgrass quality (Turgeon, 2005). Mowing height was maintained at 2.0 inches, but the study was scalped on 15 June 2004 and 2005 to 1.5 inches to further degrade turfgrass quality and promote dandelion growth and establishment (Calhoun et al., 2005). Irrigation and fertilization were increased from 6 July to 11 Nov. 2004 and 2005 because dandelions were well established and further turf loss needed to be prevented. Irrigation was applied from 6 July to 11 Nov. at 0.01 inch of water per day by an automatic irrigation system. Controlled-release fertilizer $21 \mathrm{~N}-1.3 \mathrm{P}-14.9 \mathrm{~K}$ (Country Club $^{\mathrm{TM}}$; Lebanon Turf products ${ }^{\mathrm{TM}}$ Lebanon, PA) was applied at a rate of $0.5 \mathrm{lb} / 1000 \mathrm{ft}^{2}$ (amounting to 2.4 $\mathrm{lb} / 1000 \mathrm{ft}^{2}$ fertilizer per application) on 7 July and 25 Aug. 2004 and 2005 , mowing height was maintained at 2 inches, and turfgrass clippings were returned to the plot.

Data collection. Kentucky bluegrass visual spring green-up ratings and common dandelion population counts following fall 2,4-D + MCPP + dicamba applications in 2003 were collected from April to September in 2004 and 2005. Three spring greenup ratings were recorded between 3 Apr. to 3 May 2004 and 20 Apr. to 31 May 2005, beginning about 1 month after snow-melt. Ratings were based on the National Turfgrass Evaluation Program (NTEP) system of rating, which is a measure of the transition from winter dormancy to active spring growth, using a $\mathrm{l}$ to 9 with $\mathrm{l}$ equaling straw brown color turfgrass and 9 equaling completely green turf (National Turfgrass Evaluation Program, 2008). A rating of 6 or above was considered acceptable. Individual common dandelion plants were counted monthly in each plot from June to Sept. 2004 and 2005.

STATISTICAL ANALYSIs. Data were analyzed as a factorial, randomized complete block design using PROC MIXED procedure in SAS (version 9.1; SAS Institute, Cary, NC). The three main effects were tree species, application rate, and particle size Data were analyzed at a 0.05 level of probability. Normality of the residuals and homogeneity of variances (PROC UNIVARIATE procedure) were examined, and when variances were unequal, REPEATED/GROUP = treatment statement (grouped data according to treatment) was used. Treatments with similar variances were also grouped and the unequal variances of these groups were accounted for with a REPEATED/ GROUP $=$ group statement (Littell et al., 2007). The Akaike information criterion (AIC) was used in making a final decision on whether to pursue an analysis with unequal variances or a regular analysis with a common variance (Littell et al., 2007). The analysis (unequal variance or common variance) that produced the lowest AIC value (most accurate model) was selected to make conclusions about significance of factor effects, and mean separations were obtained based on the selected analysis using Fisher's least significant difference (LSD) at a 0.05 level of probability (Ott and Longnecker, 2001). The 2004 and 2005 data were analyzed and displayed separately to evaluate the affects of two annual mulch applications over a 2 -year period after an initial broadleaf herbicide application.

\section{Results}

RESULTS OF ONE MULCH APPLICATION (2003). Significant main effects of leaf mulch application rate on kentucky bluegrass spring green-up were observed throughout the month following snowmelt, 3 and 21 Apr., and 3 May 2004 (Table 1). The high application rate, regardless of tree species, produced the greatest spring green-up followed by the low rate, and finally the control, suggesting a strong positive relationship between

Table 1. Analysis of variance results for kentucky bluegrass spring green-up ${ }^{\mathrm{z}}$ after a single application of leaf mulch in Fall 2003 at East Lansing, MI (data collected in 2004).

\begin{tabular}{|c|c|c|c|c|c|}
\hline \multirow{2}{*}{$\begin{array}{l}\text { Source of } \\
\text { variation }\end{array}$} & \multirow{2}{*}{$\begin{array}{c}\text { Numerator } \\
\text { df }\end{array}$} & \multirow{2}{*}{$\begin{array}{c}\text { Denominator } \\
\text { df }\end{array}$} & $\begin{array}{l}3 \text { Apr. } \\
2004\end{array}$ & $\begin{array}{l}21 \text { Apr. } \\
2004\end{array}$ & $\begin{array}{l}3 \text { May } \\
2004\end{array}$ \\
\hline & & & \multicolumn{3}{|c|}{$P>\mathrm{F}$} \\
\hline Leaf species $(\mathrm{L})$ & 4 & 49 & $\mathrm{NS}^{\mathrm{y}}$ & NS & NS \\
\hline Particle size $(\mathrm{P})$ & 1 & 49 & NS & NS & NS \\
\hline Application rate $(\mathrm{A})$ & 1 & 49 & $<0.0001$ & $<0.0001$ & 0.0065 \\
\hline $\mathrm{L} \times \mathrm{P}$ & 4 & 49 & NS & NS & NS \\
\hline $\mathrm{L} \times \mathrm{A}$ & 4 & 49 & NS & NS & NS \\
\hline $\mathrm{P} \times \mathrm{A}$ & 1 & 49 & NS & NS & NS \\
\hline $\mathrm{L} \times \mathrm{P} \times \mathrm{A}$ & 4 & 49 & NS & NS & NS \\
\hline
\end{tabular}

${ }^{2}$ Spring green-up was visually estimated on a 1 to 9 scale, where $1=$ brown, $9=$ completely green and $\geq 6$ acceptable. ${ }^{\mathrm{y}} \mathrm{NS}=$ not significant at $P>0.05$. 
kentucky bluegrass spring green-up and increased mulch application rates (Table 2).

Leaf species and application rate produced significant main effects on common dandelion plant counts observed after the first year of mulch, while no differences were observed between particle sizes throughout the entire data collection period (Table $3)$. A statistically significant leaf species $\times$ particle size, leaf species $\times$ application rate, and leaf species $x$ particle size $\times$ application rate interactions were also observed; however, the leaf species $\times$ particle size, and leaf species $\times$ particle size $\times$ application rate interactions were observed on one occasion only and were highly illogical, indicating a probable lack of biological significance.

Mean common dandelion counts were lowest in plots mulch with red oak followed by sugar maple and HSC sugar maple, and finally red maple and silver maple (Table 4). Throughout the 2004 data collection period, all mulch applications reduced mean dandelion populations in comparison with the control. The high mulch application rate had provided the lowest common dandelion populations, while the control had the highest dandelion populations, suggesting a strong inverse relationship. Results remained significantly different among treatments throughout the 2004 data collection period, although mean dandelion population increased over time. Leaf species $x$ application rate interactions were observed on 9 June and 7 July 2004 (data not shown), with the high application rate resulting in fewer common dandelions than the low rate for the red and sugar maple mulch on these dates, which only supports earlier statements that an inverse relationship between application rate and dandelion population was present.

RESUlTS OF TWO CONSECUTIVE MULCH APPLICATIONS (2003 AND 2004). Leaf species and application rate main effects on kentucky bluegrass spring green-up were observed after the second consecutive mulch application (Table 5 ). Species $\times$ particle sizes interactions occurred on one occasion only with highly variable and illogical mean values, possibly indicating a lack of biological significance. On 20 Apr. 2005 only, all mulch species resulted in higher kentucky bluegrass spring green-up ratings than the control (Table 6). The high application rate produced the highest greenup ratings followed by the low rate and finally the control treatment on 20 Apr., and 6 May 2005, similar to results obtained in 2004 (Table 2). As spring environmental conditions improved over time, differences in

Table 2. Effects of leaf species, particle size, and mulch application rate on mean spring green-up of kentucky bluegrass after one application of leaf mulch in Fall 2003 at East Lansing, MI (data collected in 2004).

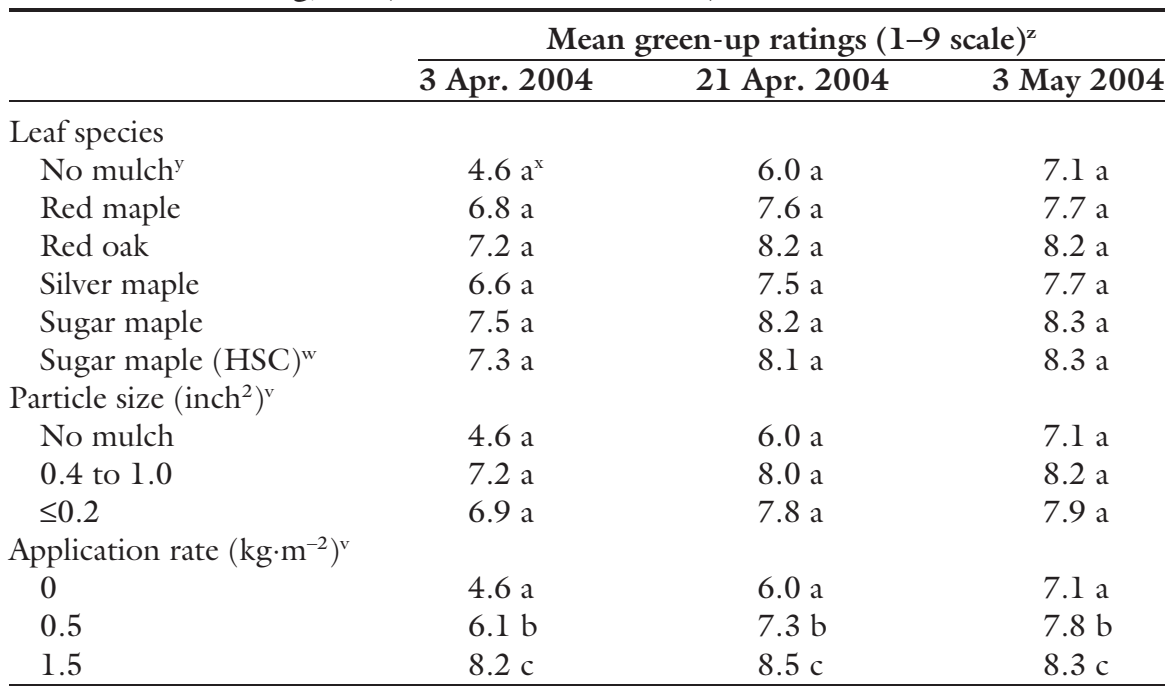

${ }^{2}$ Spring green-up was visually estimated on a $\mathrm{l}$ to 9 scale, where $\mathrm{l}=$ brown, $9=$ completely green and $\geq 6$ acceptable "Number of replications $(\mathrm{n})$ for the control $=12, \mathrm{n}$ for all other treatments $=3$.

${ }^{x}$ Means in a given column with the same letter do not differ using Fisher's least significant difference at $P=0.05$.

"HSC = high sugar content.

${ }^{v} 1$ inch $^{2}=6.4516 \mathrm{~cm}^{2}, 1 \mathrm{~kg} \cdot \mathrm{m}^{-2}=0.2048 \mathrm{lb} / \mathrm{ft}^{2}$ application rates decreased and were eventually lost on 31 May 2005.

Leaf species and application rate main effects were significant on common dandelion plant counts after a 2003 2,4-D + MCPP + dicamba herbicide application and two consecutive fall leaf mulch applications (Table 7 ). Leaf species $\times$ particle size interactions occurred on 15 June and 5 July 2005, but means were highly variable and disorderly, making the data inconclusive. When significant differences were observed on 15 June and 5 July, all leaf species applied resulted in fewer dandelions in comparison with the control, similar to results obtained in 2004 (Table 8). Sugar maple, HSC sugar maple, and red oak had the lowest common dandelion mean populations on these dates. On only one occasion (5 July 2005) did plots mulched with silver maple leaves have the lowest mean populations. On 15 June and 5 July 2005 , the high mulch application rate had fewer common dandelions than the low rate, which in turn had fewer common dandelions than the control, similar to results observed in 2004 (Table 4). Results on the last two sampling dates in 2005 were not significantly different and a substantial increase in the mean common dandelion populations was observed. As the mean common dandelion populations increased substantially over time, significance was lost due to increasing variability.

\section{Discussion}

Annual leaf mulch applications in the fall of 2003 and 2004 increased kentucky bluegrass spring green-up in the following years, suggesting that the mulched leaves had biodegraded to a point where nutrients were available to the plants, acting as an organic fertilizer (Tian et al., 1992). Similar to these findings, Christians (1993) determined that corn gluten meal provided a reliable source of nitrogen and improved kentucky bluegrass quality ratings in a fashion similar to other organic fertilizers. Acosta-Martinez et al. (1999) observed an increase in the total soil carbon and nitrogen at the 0 to $1.3 \mathrm{~cm}$ depth when maples leaves were mulched into perennial ryegrass (Lolium perenne). That research also determined that leaf mulch had no effect on soil microbial population. 
Table 3. Analysis of variance results for common dandelion populations ${ }^{\mathrm{z}}$ after a single application of leaf mulch in Fall 2003 at East Lansing, MI (data collected in 2004).

\begin{tabular}{|c|c|c|c|c|c|c|}
\hline \multirow[b]{2}{*}{ Source of variation } & \multirow{2}{*}{$\begin{array}{c}\text { Numerator } \\
\text { df }\end{array}$} & \multirow{2}{*}{$\begin{array}{c}\text { Denominator } \\
\text { df }\end{array}$} & $\begin{array}{l}9 \text { June } \\
2004\end{array}$ & $\begin{array}{l}7 \text { July } \\
2004\end{array}$ & $\begin{array}{l}3 \text { Aug. } \\
2004\end{array}$ & $\begin{array}{c}1 \text { Sept. } \\
2004\end{array}$ \\
\hline & & & \multicolumn{4}{|c|}{$P>\mathrm{F}$} \\
\hline Leaf species $(\mathrm{L})$ & 4 & 49 & $\mathrm{NS}^{\mathrm{y}}$ & 0.0420 & 0.0501 & 0.0404 \\
\hline Particle size $(\mathrm{P})$ & 1 & 49 & NS & NS & NS & NS \\
\hline Application rate $(\mathrm{A})$ & 1 & 49 & 0.0028 & $<0.0001$ & 0.0002 & $<0.0001$ \\
\hline $\mathrm{L} \times \mathrm{P}$ & 4 & 49 & NS & NS & NS & 0.0474 \\
\hline $\mathrm{L} \times \mathrm{P} \times \mathrm{A}$ & 4 & 49 & NS & NS & 0.0050 & NS \\
\hline
\end{tabular}

${ }^{\mathrm{z}}$ Common dandelion plants per $30-\mathrm{ft}^{2}\left(2.8 \mathrm{~m}^{2}\right)$ plot; $\mathrm{l}$ plant $/ 30 \mathrm{ft}^{2}=0.3588$ plants $/ \mathrm{m}^{2}$.

${ }^{\mathrm{y}_{\mathrm{NS}}}=$ not significant at $P>0.05$.

Table 4. Effects of leaf species, particle size, and mulch application rate on mean common dandelion populations after one application of leaf mulch in Fall 2003 at East Lansing, MI (data collected in 2004).

\begin{tabular}{lcccc}
\hline & \multicolumn{4}{c}{ Mean dandelion populations (plants/30 $\left.\mathrm{ft}^{2}\right)^{\mathrm{z}}$} \\
\cline { 2 - 5 } & 9 June 2004 & 7 July 2004 & 3 Aug. 2004 & 1 Sept. 2004 \\
\hline Leaf species & $8.0 \mathrm{a}^{\mathrm{x}}$ & $21.4 \mathrm{a}$ & $36.8 \mathrm{a}$ & $38.3 \mathrm{a}$ \\
No mulch & & & & \\
Red maple & $2.5 \mathrm{a}$ & $7.7 \mathrm{~b}$ & $18.7 \mathrm{bc}$ & $22.1 \mathrm{~b}$ \\
Red oak & $2.3 \mathrm{a}$ & $7.0 \mathrm{bc}$ & $17.6 \mathrm{bc}$ & $18.8 \mathrm{bc}$ \\
Silver maple & $1.6 \mathrm{a}$ & $9.3 \mathrm{~b}$ & $20.9 \mathrm{~b}$ & $21.4 \mathrm{bc}$ \\
Sugar maple & $2.6 \mathrm{a}$ & $4.2 \mathrm{c}$ & $19.1 \mathrm{bc}$ & $22.6 \mathrm{~b}$ \\
Sugar maple $(H S C)^{\mathrm{w}}$ & $1.9 \mathrm{a}$ & $8.3 \mathrm{~b}$ & $15.2 \mathrm{c}$ & $17.1 \mathrm{c}$ \\
Particle size (inch $)^{\mathrm{v}}$ & & & & \\
No mulch & $8.0 \mathrm{a}$ & $21.4 \mathrm{a}$ & $36.8 \mathrm{a}$ & $38.3 \mathrm{a}$ \\
0.4 to 1.0 & $2.1 \mathrm{a}$ & $7.4 \mathrm{a}$ & $17.8 \mathrm{a}$ & $20.1 \mathrm{a}$ \\
$\leq 0.2$ & $2.2 \mathrm{a}$ & $7.9 \mathrm{a}$ & $18.8 \mathrm{a}$ & $20.4 \mathrm{a}$ \\
Application rate $\left(\mathrm{kg} \cdot \mathrm{m}^{-2}\right)^{\mathrm{v}}$ & & & & \\
0 & $8.0 \mathrm{a}$ & $21.4 \mathrm{a}$ & $36.8 \mathrm{a}$ & $38.3 \mathrm{a}$ \\
0.5 & $3.0 \mathrm{~b}$ & $11.1 \mathrm{~b}$ & $21.3 \mathrm{~b}$ & $22.7 \mathrm{~b}$ \\
1.5 & $1.6 \mathrm{c}$ & $6.2 \mathrm{c}$ & $15.9 \mathrm{c}$ & $16.9 \mathrm{c}$ \\
\hline
\end{tabular}

${ }^{\mathrm{z}}$ Common dandelion plants per $30-\mathrm{ft}^{2}\left(2.8 \mathrm{~m}^{2}\right)$ plot; 1 plant $/ 30 \mathrm{ft}^{2}=0.3588$ plants $/ \mathrm{m}^{2}$.

${ }^{y}$ Number of replications $(\mathrm{n})$ for the control $=12, \mathrm{n}$ for all other treatments $=3$.

${ }^{x}$ Means in a given column with the same letter do not differ using Fisher's least significant difference at $P=0.05$.

${ }^{\text {w } H S C}=$ high sugar content.

${ }^{v} 1$ inch $^{2}=6.4516 \mathrm{~cm}^{2}, 1 \mathrm{~kg} \cdot \mathrm{m}^{-2}=0.2048 \mathrm{lb} / \mathrm{ft}^{2}$.

Table 5. Analysis of variance results for kentucky bluegrass spring green-up ${ }^{z}$ after applications of leaf mulch in Fall 2003 and 2004 at East Lansing, MI (data collected in 2005).

\begin{tabular}{|c|c|c|c|c|c|}
\hline \multirow{2}{*}{$\begin{array}{l}\text { Source of } \\
\text { variation }\end{array}$} & \multirow{2}{*}{$\begin{array}{c}\text { Numerator } \\
\text { df }\end{array}$} & \multirow{2}{*}{$\begin{array}{c}\text { Denominator } \\
\text { df }\end{array}$} & $\begin{array}{c}20 \text { Apr. } \\
2005\end{array}$ & $\begin{array}{l}6 \text { May } \\
2005\end{array}$ & $\begin{array}{c}31 \text { May } \\
2005\end{array}$ \\
\hline & & & \multicolumn{3}{|c|}{$P>\mathrm{F}$} \\
\hline Leaf species (L) & 4 & 49 & 0.0007 & $\mathrm{NS}^{\mathrm{y}}$ & NS \\
\hline Particle size (P) & 1 & 49 & NS & NS & NS \\
\hline Application rate (A) & 1 & 49 & $<0.0001$ & $<0.0001$ & NS \\
\hline $\mathrm{L} \times \mathrm{P}$ & 4 & 49 & 0.0237 & NS & NS \\
\hline $\mathrm{L} \times \mathrm{A}$ & 4 & 49 & NS & NS & NS \\
\hline $\mathrm{P} \times \mathrm{A}$ & 1 & 49 & NS & NS & NS \\
\hline $\mathrm{L} \times \mathrm{P} \times \mathrm{A}$ & 4 & 49 & NS & NS & NS \\
\hline
\end{tabular}

${ }^{\mathrm{z}}$ Spring green-up was visually estimated on a 1 to 9 scale, where $\mathrm{l}=$ brown, $9=$ completely green and $\geq 6$ acceptable. ${ }^{\mathrm{N}} \mathrm{NS}=$ not significant $P>0.05$.

All leaf mulch treatments, regardless of species, decreased dandelion populations in comparison with the control at relatively low common dandelion populations, $<100$ common dandelions per plot $\left(30 \mathrm{ft}^{2}\right)$. When mean values and the number of significant differences between treatments collected over the 2-year period are evaluated, the red oak leaf mulch produced the most consistent common dandelion control followed by sugar maple and HSC sugar maple, silver maple, and red maple. Results obtained by Nikolai et al. (1998) also observed reduced dandelion populations in plots mulched with maple leaves, but did not observe reduced dandelion populations as a result of oak leaf applications. Conversely, Lodhi (1976) determined that decaying leaves, leaf leachates, and soil collected from under red oak, the oak species that was selected for the present research, possessed several growth inhibitory phenolic compounds such as scopolin, caffeic acid, and ferulic acid, which reduced germination, radicle growth, and seedling growth of japanese brome (Bromus japonicus), canada wild rye (Elymus canadensis), and coralberry (Symphoricarpos orbiculatus).

An inverse relationship was observed between leaf mulch application rates and common dandelion populations, with the high application rate providing the greatest common dandelion control. Tompkins et al. (2004) also observed that as organic weed control product rates increased, the number of common dandelions per unit area decreased. Christians (1993) observed that corn gluten meal applied at $99 \mathrm{~g} \cdot \mathrm{m}^{-2}$ product provided $58 \%$ control of crabgrass (Digitaria sanguinalis), while $594 \mathrm{~g} \cdot \mathrm{m}^{-2}$ product provided $97 \%$ control. In that research, a variety of corn byproducts (corn starch, corn germ, corn fiber, and corn meal) and a slow-release fertilizer (Milorganite $^{\circledR}$; Milwaukee Sewerage District, Milwaukee) reduced creeping bentgrass (Agrostis palustris) and crabgrass establishment, which was 
Table 6. Effects of leaf species, particle size, and mulch application rate on mean spring green-up of kentucky bluegrass after applications of leaf mulch in Fall 2003 and 2004 at East Lansing, MI (data collected in 2005).

\begin{tabular}{|c|c|c|c|}
\hline & \multicolumn{3}{|c|}{ Mean green-up ratings $(1-9 \text { scale })^{\mathrm{z}}$} \\
\hline & 20 Apr. 2005 & 6 May 2005 & 31 May 2005 \\
\hline \multicolumn{4}{|l|}{ Leaf species } \\
\hline No mulch ${ }^{y}$ & $4.8 \mathrm{a}^{\mathrm{x}}$ & $6.6 \mathrm{a}$ & $7.0 \mathrm{a}$ \\
\hline Red maple & $7.8 \mathrm{c}$ & $8.5 \mathrm{a}$ & $7.0 \mathrm{a}$ \\
\hline Red oak & $6.8 \mathrm{~b}$ & $8.1 \mathrm{a}$ & $7.2 \mathrm{a}$ \\
\hline Silver maple & $7.9 \mathrm{c}$ & $8.5 \mathrm{a}$ & $7.3 \mathrm{a}$ \\
\hline Sugar maple & $7.3 \mathrm{bc}$ & $8.2 \mathrm{a}$ & $7.1 \mathrm{a}$ \\
\hline Sugar maple (HSC) ${ }^{\mathrm{w}}$ & $7.4 \mathrm{bc}$ & $8.4 \mathrm{a}$ & $7.0 \mathrm{a}$ \\
\hline \multicolumn{4}{|l|}{ Particle size $\left(\text { inch }^{2}\right)^{\mathrm{v}}$} \\
\hline No mulch & $4.8 \mathrm{a}$ & $6.6 \mathrm{a}$ & $7.0 \mathrm{a}$ \\
\hline 0.4 to 1.0 & $7.4 \mathrm{a}$ & $8.3 \mathrm{a}$ & $7.2 \mathrm{a}$ \\
\hline$\leq 0.2$ & $7.5 \mathrm{a}$ & $8.4 \mathrm{a}$ & $7.0 \mathrm{a}$ \\
\hline \multicolumn{4}{|l|}{ Application rate $\left(\mathrm{kg} \cdot \mathrm{m}^{-2}\right)^{\mathrm{v}}$} \\
\hline 0 & $4.8 \mathrm{a}$ & $6.6 \mathrm{a}$ & $7.0 \mathrm{a}$ \\
\hline 0.5 & $6.6 \mathrm{~b}$ & $8.0 \mathrm{~b}$ & $7.1 \mathrm{a}$ \\
\hline 1.5 & $8.3 \mathrm{c}$ & $8.7 \mathrm{c}$ & $7.1 \mathrm{a}$ \\
\hline
\end{tabular}

${ }^{2}$ Spring green-up was visually estimated on a $\mathrm{l}$ to 9 scale, where $\mathrm{l}=$ brown, $9=$ completely green and $\geq 6$ acceptable. 'Number of replications $(\mathrm{n})$ for the control $=12, \mathrm{n}$ for all other treatments $=3$.

${ }^{x}$ Means in a given column with the same letter do not differ using Fisher's least significant difference at $P=0.05$. "HSC = high sugar content.

${ }^{v} 1$ inch $^{2}=6.4516 \mathrm{~cm}^{2}, 1 \mathrm{~kg} \cdot \mathrm{m}^{-2}=0.2048 \mathrm{lb} / \mathrm{ft}^{2}$.

attributed to a mulching effect. Letchamo and Gosselin (1996) reported that common dandelion seed germinated faster and more uniformly at or above a $1.0 \mathrm{~cm}$ soil depth, and when continuous light (400-700 $\mu \mathrm{m})$ was provided. When these findings are taken into consideration, it is possible that mulch applications functioned as a physical barrier that prevented sunlight from reaching the seeds during the fall, a period of the year favorable to common dandelion germination (Uva et al., 1997).

Mulch barriers not only prevent sunlight from reaching the soil surface, but also have an effect on a variety of environmental inputs such as temperature and moisture content. Kowalewski (2006) observed a slight increase $\left(1.2-3.2^{\circ} \mathrm{C}\right)$ in soil surface temperature when leaf mulch was still present in the early spring after it was applied in the fall. Letchamo and Gosselin (1996) observed greater common dandelion germination at higher ambient temperatures. Therefore, if soil surface temperature is the only factor taken into consideration, mulched leaves would have been expected to increase common dandelion germination in the spring, unlike the results observed in this research.

After the first mulch application, the high rate provided the greatest common dandelion control, up to $80 \%$ in 2004 , which is considered control by the Pest Management Regulatory Agency (Pest Management Regulatory Agency, 2002; Tompkins et al., 2004). However, two consecutive leaf mulch applications
(2003 and 2004), without herbicide applications, at the high mulch rate provided up to $53 \%$ common dandelion control. Christians (1993) observed better control from corn gluten meal applied 1 week before crabgrass germination in comparison with applications made 4 weeks before germination, and a reduction in creeping bentgrass control when it was used as a medium for microbial activity. In that research, it was hypothesized that microbial activity had reduced the effectiveness of the plant inhibitory compounds. When these results are taken into consideration, it is possible that leaf mulch applications applied in the fall inhibited common dandelion germination in the fall, during its secondary flowering peak, but did not provide any inhibitory effects in the spring, during the primary flowering peak, after soil microbes had degraded potential inhibitory compounds, resulting in an eventual loss of weed control over a 2-year period (Gray et al., 1973). Common dandelion seeds are born viable and have been shown to provide poor seed survival or induced dormancy, suggesting that maximum germination will occur upon seed dispersal (Bostock, 1978; Letchamo and Gosselin, 1996). It is also important to note that organically derived weed control products typically provide relatively low levels of control (Bingaman and Christians, 1995) compared with synthetic herbicides. When these results are contrasted to kentucky bluegrass spring green-up findings, it also seems likely that leaf mulch applications may have functioned as an organic fertilizer, improving the competitive ability of the kentucky bluegrass, which in turn decreased dandelion seed germination

Table 7. Analysis of variance results for dandelion populations ${ }^{\mathrm{z}}$ after applications of leaf mulch in Fall 2003 and 2004 at East Lansing, MI (data collected in 2005).

\begin{tabular}{|c|c|c|c|c|c|c|}
\hline \multirow[b]{2}{*}{ Source of variation } & \multirow{2}{*}{$\begin{array}{c}\text { Numerator } \\
\text { df }\end{array}$} & \multirow{2}{*}{$\begin{array}{c}\text { Denominator } \\
\text { df }\end{array}$} & 15 June 2005 & 5 July 2005 & 1 Aug. 2005 & 6 Sept. 2005 \\
\hline & & & \multicolumn{4}{|c|}{$P>\mathrm{F}$} \\
\hline Leaf species $(\mathrm{L})$ & 4 & 49 & 0.0076 & 0.0243 & $\mathrm{NS}^{\mathrm{y}}$ & NS \\
\hline Application rate $(\mathrm{A})$ & 1 & 49 & $<0.0001$ & 0.0355 & NS & NS \\
\hline $\mathrm{L} \times \mathrm{P}$ & 4 & 49 & 0.0068 & 0.0072 & NS & NS \\
\hline $\mathrm{L} \times \mathrm{A}$ & 4 & 49 & NS & NS & NS & NS \\
\hline
\end{tabular}

${ }^{2}$ Common dandelion plants per $30-\mathrm{ft}^{2}\left(2.8 \mathrm{~m}^{2}\right)$ plot; 1 plant $/ 30 \mathrm{ft}^{2}=0.3588$ plants $/ \mathrm{m}^{2}$.

${ }^{y_{N S}}=$ not significant at $P>0.05$. 
Table 8. Effects of leaf species, particle size, and application rate on mean dandelion populations after applications of leaf mulch in Fall 2003 and 2004 at East Lansing, MI (data collected in 2005).

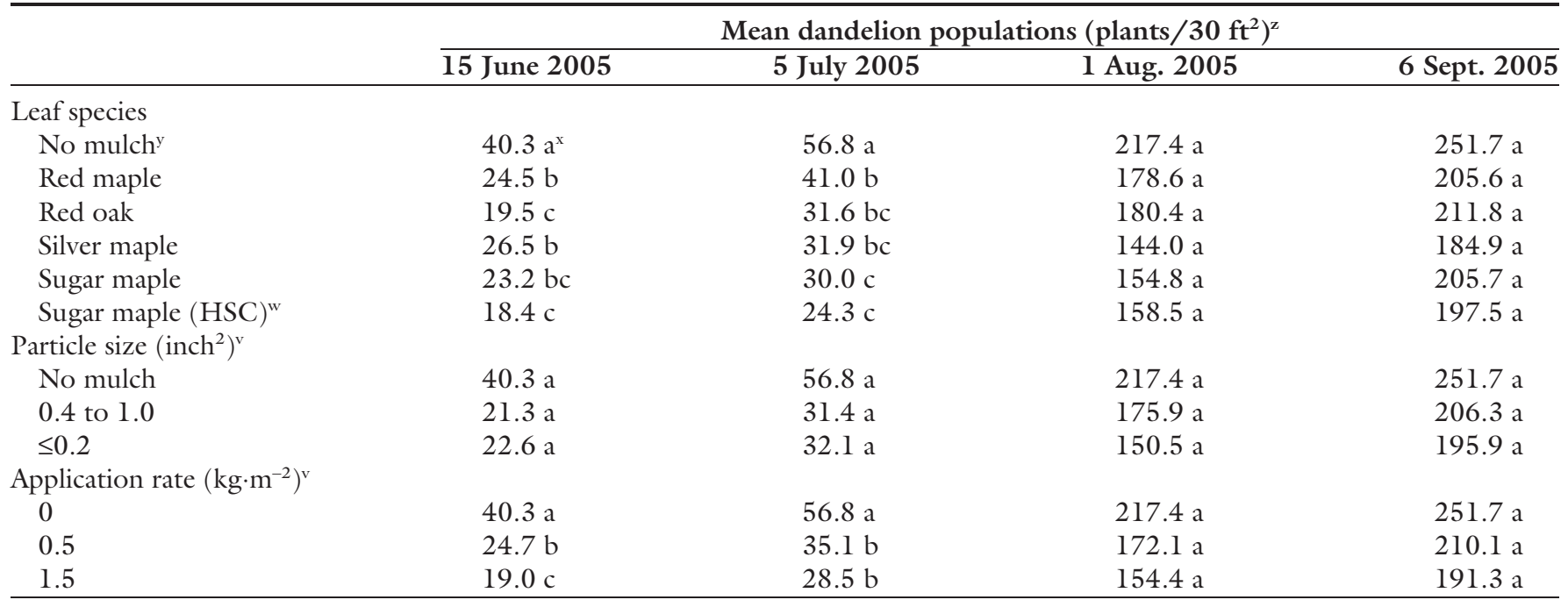

${ }^{\mathrm{z} C o m m o n}$ dandelion plants per $30-\mathrm{ft}^{2}\left(2.8 \mathrm{~m}^{2}\right)$ plot; 1 plant $/ 30 \mathrm{ft}^{2}=0.3588$ plants $/ \mathrm{m}^{2}$.

Number of replications $(\mathrm{n})$ for the control $=12, \mathrm{n}$ for all other treatments $=3$.

${ }^{x}$ Means in a given column with the same letter do not differ using Fisher's least significant difference at $P=0.05$.

${ }^{\text {w }} \mathrm{HSC}=$ high sugar content.

${ }^{\mathrm{v}} \mathrm{l} \mathrm{inch}^{2}=6.4516 \mathrm{~cm}^{2}, \mathrm{l} \mathrm{kg} \cdot \mathrm{m}^{-2}=0.2048 \mathrm{lb} / \mathrm{ft}^{2}$.

during its major flush in the early spring (Turner et al., 1979; Uva et al., 1997).

The turfgrass in this research was maintained at a minimal level and regularly scalped to promote common dandelion establishment; therefore, the substantial increase in common dandelion populations observed throughout the experiment was not completely unexpected. Consequently, when incorporating organically derived weed control products into a turfgrass management regime, it is particularly important to promote turfgrass health and vigor with proper mowing, fertilization, and irrigation to increase the competitive ability of the grass (Busey, 2003). Results from this research do not suggest that mulching leaves can be used exclusively as an alternative to herbicides to provide high-end weed control. However, if home owners wanted to incorporate this practice into an annual maintenance program, the findings observed in this research suggest that an increased spring green-up and a reduction in common dandelion population could be observed. It is also important to note that a wide variety of research has been conducted on leaf mulch and has determined that it produces no negative effects on turf density, shoot growth, thatch accumulation, soil organic matter content, soil $\mathrm{pH}$, infiltration rates, or soil bulk density (Acosta-Martinez et al., 1999; Nektarios et al., 1999).

Currently, research is being conducted to evaluate the effects of mulched tree leaves on common dandelion control in combination with various mowing heights and fertilization levels. The objectives of this research are to determine if the results observed in this research were simply due to nutrients provided by the leaf mulch, which improved turfgrass competition during dandelion germination periods, and if leaf mulch can provide an effective long-term weed control method when turfgrass management practices are improved. Current research is also comparing the effects of mulched leaves in comparison with mulched newspaper to determine if the results observed in this research were simply the effects of a physical barrier that prevented common dandelion germination. Future research will be required to determine the exact mechanism (chemical) or mechanisms of weed control if current research determines that common dandelion reduction is not the effect of organically derived nutrients or a mulch barrier.

\section{Literature cited}

Acosta-Martinez, V., Z. Reicher, M. Bischoff, and R.F. Turco. 1999. The role of tree leaf mulch and nitrogen fertilizer on turfgrass soil quality. Biol. Fertil. Soils 29:55-61.

Association of Official Seed Analysts. 2002. Rules for testing seed. Association of Official Seed Analysts, Stillwater, OK.

Bingaman, B.R. and N.E. Christians. 1995. Greenhouse screening of corn gluten meal as a natural control product for broadleaf and grass weeds. HortScience 30:1256-1259.

Bostock, S.J. 1978. Seed germination strategies of five perennial weeds. Osecologia 36:113-126.

Busey, P. 2003. Cultural management of weeds in turfgrass: A review. Crop Sci. 43: 1899-1911.

Calhoun, R.N., G.J. Reinhart, A.D. Hathaway, and D.D. Buhler. 2005. Maximizing cultural practices to minimize weed pressure and extend herbicide treatment intervals in a cool-season turfgrass mixture. Intl. Turfgrass Soc. Res. J. 10: 1184-1188.

Christians, N.E. 1993. The use of corn gluten meal as a natural preemergence weed control in turf. Intl. Turfgrass Soc. Res. J. 7:284-290.

Gray, E., E.M. McGehre, and D.F. Carlisle. 1973. Seasonal variation in flowering of common dandelion. Weed Sci. 21:230-232.

Kowalewski, A.R. 2006. Organically derived weed control methods. Michigan State University. East Lansing, M.S. Thesis. 
Letchamo, W. and A. Gosselin. 1996. Light, temperature, and duration of storage govern the germination and emergence of Taraxacum officinale seed. J. Hort. Sci. 71:373-377.

Littell, R.C., G.A. Milliken, W.W. Stroup, R.D. Wolfinger, and O. Schabenberger. 2007. SAS for mixed models. 2 nd ed. SAS Institute, Cary, NC.

Lodhi, M.A.K. 1976. Role of allelopathy as expressed by dominating trees in a lowland forest in controlling the productivity and pattern of herbaceous growth. Amer. J. Bot. 63:1-8.

National Resources Conservation Services. 2005. Web soil survey. I Dec. 2005. <http://websoilsurvey.nrcs.usda.gov/ app $/>$.

National Turfgrass Evaluation Program. 2008. A guide to NTEP turfgrass ratings. 15 Jan. 2008. <http://www.ntep.org/ reports/ratings.htm $>$.

Nektarios, P., A.M. Petrovic, and D. Sender. 1999. Tree leaf decomposition effects on kentucky bluegrass (Poa pratensis L.). J. Turfgrass Mgt. 3:69-74.

Nikolai, T.A., P.E. Rieke, and N.T. McVay. 1998. Leaf mulch forum "research and real-world techniques." 68th Ann. Michigan Turfgrass Conf. Proc. 27: 66-68.

Ott, R.M. and M. Longnecker. 2001. An introduction to statistical methods and data analysis. 5th ed. Duxbury, Pacific Grove, CA.

Pest Management Regulatory Agency. 2002. Regulatory directive; DIR2003-04. 4 Mar. 2008. <http://www.pmraarla.gc.ca/english/pdf/dir/dir2003-04-e. pdfs.

Starrett, S.K., N.E. Christians, and T.A. Austin. 2000. Movement of herbicides under two irrigation regimes applied to turfgrass. Adv. Environ. Res. 4:167179.

Stevens, O.A. 1957. Weights of seeds and numbers per plant. Weeds 5:46-55.
Tian, G., B.T. Kang, and L. Brassaard. 1992. Biological effects of plant residues with contrasting chemical compositions under humid tropical conditions: Decomposition and nutrient release. Soil Biol. Biochem. 24:1051-1060.

Tompkins, D.K., C. Bubar, J.B. Ross, and M.A. Anderson. 2004. Evaluation of agricultural by-products for the control of weeds in turfgrass. 2004 Western Canada Turfgrass Assn. Res. Rpt. 20-30.

Turgeon, A.J. 2005. Turfgrass management. 7th ed Pearson Education, Upper Saddle River, NJ.

Turner, T.R., D.V. Waddington, and T.L. Watschke. 1979. The effect of soil fertility levels on dandelion and crabgrass encroachment of Merion kentucky bluegrass. Proc. 33rd Northeastern Weed Sci. Soc. Conf. 280-286.

Uva, R.U., J.C. Neal, and J.M. DiTomaso. 1997. Weeds of the Northeast. Cornell University Press, Ithaca, NY. 